$\mathrm{pH}$ 순환 모형을 이용하여 $15 \%$ 과산화요소를 함유한 치아미 백제가 심미수복재의 색, 미세경도 및 거칠기에 미치는 영향

박소영 · 송민지 ${ }^{1} \cdot$ 전수영 $^{1} \cdot$ 김선영 $^{1} \cdot$ 심연수 $^{1}$

원광대학교 치과대학 예방치과학교실 $\cdot{ }^{1}$ 청주대학교 치위생학과

\title{
The effect of tooth bleaching agent contained $15 \%$ carbamide peroxide on the color, microhardness and surface roughness of tooth-colored restorative materials by using $\mathrm{pH}$ cycling model
}

So-Young Park $\cdot$ Min-Ji Song ${ }^{1} \cdot \mathrm{Su}-$ Young Jeon $^{1} \cdot \mathrm{Sun}^{-}$-Young $\mathrm{Kim}^{1} \cdot$ Youn-Soo Shim ${ }^{1}$ Department of Preventive and Public Health Dentistry, College of Dentistry, Wonkwang University ${ }^{1}$ Department of Dental Hygiene, Cheongiu University

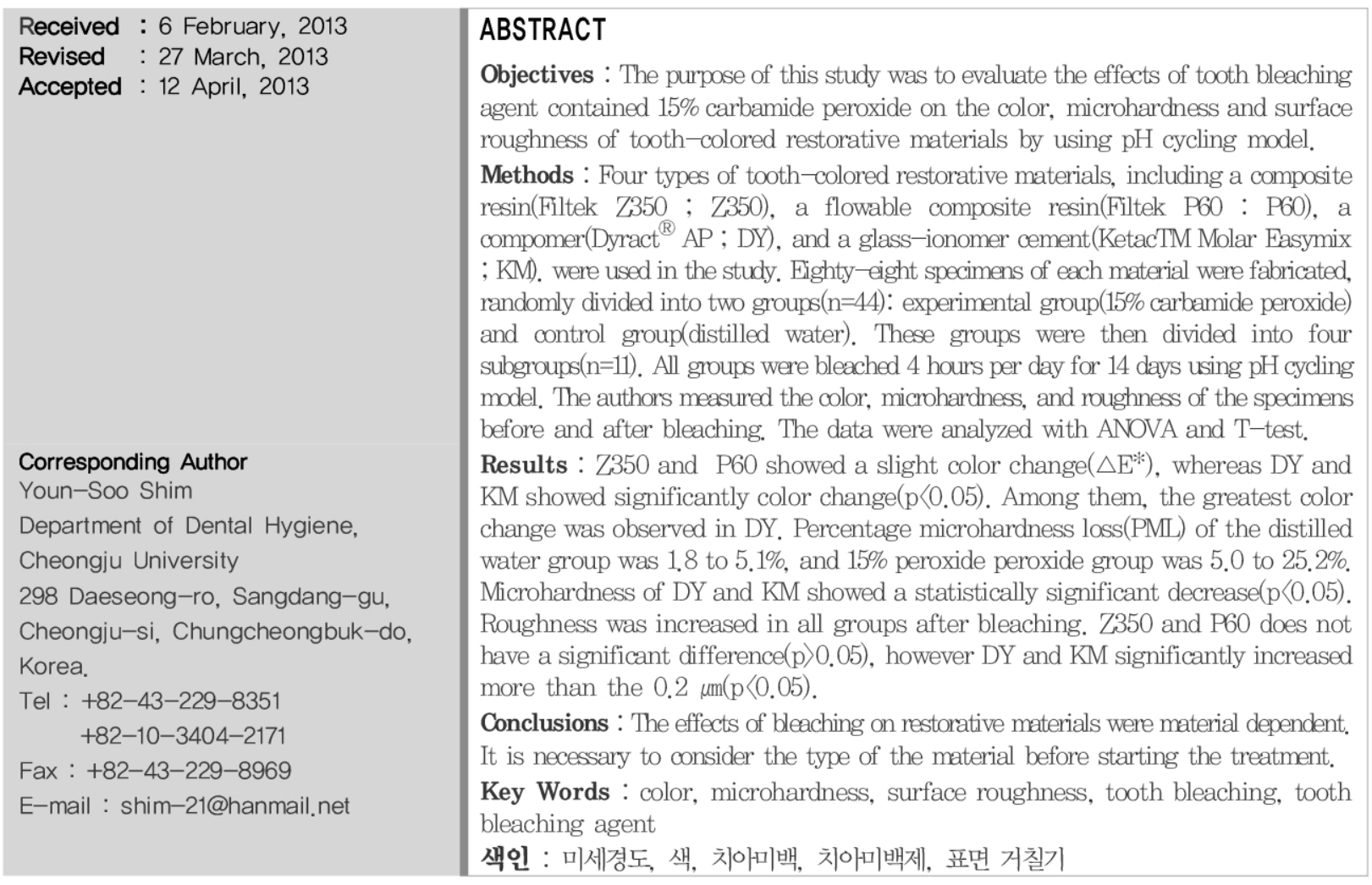

Copytight(C2013 by Journal of Korean Society of Dental Hygiene

This is an open-access article distributed under the terms of the Creative Commons Attribution Non-Commercial License (http://creativecommons.org/ licenses/by-nc/3.0/), which permits unrestricted non-commercial use, distribution, and reproduction in medium, provided the original work is properly cited. 


\section{서론}

최근 사회적 문화적 발전과 함께 생활수준이 높아지고 환 자들의 심미적 요구가 늘어났다. ${ }^{1)}$ 치아변색을 일으키는 주요 원인은 선천적 혹은 후천적으로 치아가 변색되는 경우가 있 는데 이것은 내인성 변색, 외인성 변색 또는 이 두가지의 복합 적 작용에 의한 변색으로 분류할 수 있다 ${ }^{2}$. 내인성 변색의 경우 치아가 맹출 한 이후나 치아 형성기 동안에 색소물질이 상아질이나 법랑질에 유입되어 발생한다. 발생중인 치아가 고농도의 불소에 노출되거나, 테트라사이클린의 투약, 유전 적인 발생 부전, 그리고 외상 등에 의해 영향 받을 경우 맹출 전 변색이 생길 수 있다. 치아가 맹출한 후에는 노화, 치수 괴사, 그리고 의원성 요인 등이 내인성 변색의 주 원인이 될 수 있다. 외인성 변색은 커피, 차, 적포도주, 당근, 오렌지, 그리고 흡연 등으로 인해 발생한다. 치아의 마모, 노화에 의 한 2 차 상아질의 침착이나 치수 염증에 의한 결과 또는 상아 질 경화증 등은 치아의 빛 투과 성질에 영향을 주어서 점차적 으로 치아색을 어둡게 만든달) 이런 다양한 형태의 변색은 심미성 저하로 인해 본인 스스로 열등감 및 콤플렉스로 반영 되어 대인관계에도 영향을 줄 수 있다. 따라서 자연스런 색상 으로 복원시켜 주기 위해 다양한 방법이 이용되고 있다. 그중 대표적인 심미치료 중 하나가 치아미백으로 종전의 치아를 삭제하는 도재 수복 등의 보철적인 방법보다 치질을 보존하 면서 간편하고 편리한 치료방법으로 심미성을 회복시켜주는 시술로 최근 널리 이용되고 있다. 최초의 생활치 미백은 1877 년 Chapple이 옥살산(oxalic acid)으로 시도하였고, 1884년 Harlan이 최초로 과산화수소(hydrogen peroxide, HP)를 사용 하였다 ${ }^{3)}$. 생활치 미백은 1989년 Haywood 와 Heymann ${ }^{4}$ 에 의해 $10 \%$ 과산화요소(carbamide peroxide, $\mathrm{CP}$ )를 가정에서 개인 트레이에 적용하는 자가미백술을 소개하면서 치과영역 의 한 술식으로 급속히 확산되었고, 1991 년에는 $30 \%$ 과산화 수소와 고강도 광원을 함께 사용하면서 미백제의 온도를 상 승시켜 화학반응을 촉진시키는 방법으로 진료실에서 이뤄지 는 전문가 미백술로서 현재는 진료실에서 자가 미백술과 전 문가 미백술을 병행하면서 임상에서 활용하고 있다 ${ }^{1)}$.

또 다른 심미치료로는 심미수복재를 이용한 수복치료이다. 심미수복재는 치과용 합금이나 아말감 대신 자연치아와 유사 한 색조를 갖는 재료로서 수복하거나 충전을 하며, 종류로는 복합레진(composite resin), 글라스 아이오노머(glass ionomer), 레진 강화형 글라스 아이오노머(resin-modified glass ionomer, RMGI), 컴포머(compomer) 등이 있닫). 이러한 심 미 수복재는 현대 치과계의 필수적이면서 중요한 부분으로 자리매김 되고 있다. 이러한 추세를 반영하듯, 최근에 발표된
연구에서는 수복물을 가진 환자들에 대한 치아미백이 증가하 면서 치아 및 수복재에 대한 치아 미백제의 영향에 대한 연구 가 많이 이루어지고 있다. 여기에는 표면 형태의 변화와 수복 재의 화학적 물리적 특성의 변화가 이에 해당된다.

심미수복재을 이용한 수복 치료 시 치료의 성공요인으로는 물리적 특성과 심미적인 요인을 들 수 있으며, 물리적 특성에 는 강도와 마모 저항성이며 심미적인 요인으로는 색 안정성, 법랑질과 유사한 방사선 불투과성 등이 해당된다 ${ }^{\natural}$. 이러한 특성들이 수복 후 구강 내에서 유지되어야 하며, 다른 시술로 인해 부작용이 나타나서는 안 된다.

Monaghan 등근 저농도의 과산화수소를 적용했을 때 복합 레진의 색상 변화가 적었지만, 고농도의 과산화수소에서는 색상 변화를 보였다고 하였다. Cooley와 Burger ${ }^{8}$ 의 색차계를 이용한 연구에서는 $10 \%$ 과산화요소 미백제로 인하여 복합레 진의 색이 밝아졌다고 하였다. Taher"는 복합 레진과 ormocer, 그리고 레진 강화형 글라스 아이오노머를 15\% 과산화 요소와 $35 \%$ 과산화수소로 미백했을 때, 표면 연화 효과와 미세 경도 감소를 보였으나, 동일한 미백제를 적용했던 컴포 머는 미세경도가 증가하였다고 하였다. Turker와 Biskin ${ }^{10}$ 의 연구에서는 치아미백제가 심미수복재의 거칠기에도 영향을 주며 특히 레진강화형 글래스 아이오노머에 가장 큰 변화가 있다고 하였다. Bailey와 Swift ${ }^{11}$ 의 연구에서는 자가미백제가 일부 복합 레진 수복재의 표면 거칠기에 영향을 미친다고 하였다. Mor 등 ${ }^{12}$ 은 $10 \%$ 의 과산화수소로 미백한 후 거칠기로 인해 균의 표면 접착을 유의하게 증가시킨다는 것을 발견하 였다. Yalcin과 Gürgan ${ }^{13)}$ 의 연구에서는 두 가지 다른 치아미 백제(젤과 스트립)를 이용하여 심미수복재의 광택(gloss)을 본 결과, 두 가지 방법 모두 미백 후 광택 감소가 보이며 특히, 스트립 방법은 젤 방법보다 Filtek P60과 Filtek Flow의 광택 변화에 더 유의한 감소를 보였다.

이에 본 연구는 $35 \%$ 과산화수소를 이용한 전문가 미백에서 수복재에 미치는 영향하에 대한 후속 연구로서, 구강 내 상태 를 재현하기 위해 $\mathrm{pH}$ 순환 모형을 이용하여 $15 \%$ 과산화요소 를 함유한 치아미백제가 심미수복재의 색과 미세경도 및 거 칠기에 미치는 영향에 대해 연구하고자 한다.

\section{연구대상 및 방법}

\section{1. 연구재료}

본 연구에서 사용한 심미수복재는 복합레진 Filtek Z350(3M ESPE, MN, USA)과 Filtek P60(3M ESPE, MN, USA), 컴포머 Dyract ${ }^{\circledR} \mathrm{AP}($ Dentsply, Konstanz, Germany), 그리고 글라스 
Table 1. Materials used in this study

\begin{tabular}{|c|c|c|c|c|}
\hline Materials & Code & Type & Main composition & Manufacturer \\
\hline Filtek Z350 & $\mathrm{Z} 350$ & $\begin{array}{l}\text { Nanohybrid composite } \\
\text { resin }\end{array}$ & $\begin{array}{l}\text { combination of aggregated zirkonia/silica } \\
\text { cluster filler, Bis-GMA, UDMA, } \\
\text { TEGDMA, Bis-EMA }\end{array}$ & 3M ESPE, MN, USA \\
\hline Filtek P60 & $\mathrm{P} 60$ & $\begin{array}{l}\text { Packable composite } \\
\text { resin }\end{array}$ & $\begin{array}{l}\text { Zirconia/silica filler, bis-GMA, UDMA } \\
\text { and bis-EMA resins }\end{array}$ & 3M ESPE, MN, USA \\
\hline Dyract ${ }^{(R)} \mathrm{AP}$ & DY & $\begin{array}{l}\text { Polyacid- modified } \\
\text { composite(Compomer) }\end{array}$ & $\begin{array}{l}\text { Alkanoyl-poly-methacrylate, UDMA,TCB } \\
\text { resin, Strontium-fluoro-silicate glass, } \\
\text { Strontium fluoride, Photo initiators, Butyl } \\
\text { hydroxy toluene, Iron oxide pigments }\end{array}$ & $\begin{array}{l}\text { Densply Detrey } \\
\text { Gmbh,Konstanz, Germany }\end{array}$ \\
\hline $\begin{array}{l}\text { Ketac }^{\mathrm{TM}} \text { Molar } \\
\text { Easymix }\end{array}$ & $\mathrm{KM}$ & $\begin{array}{l}\text { Conventional } \\
\text { Glass-ionomer cement }\end{array}$ & $\begin{array}{l}\text { Aluminium-calcium-lanthanum } \\
\text { fluorosilicate glass, polycarboxylic acid }\end{array}$ & $\begin{array}{l}\text { 3M ESPE, Seefeld, } \\
\text { Germany }\end{array}$ \\
\hline $\begin{array}{l}\text { Opalescence } \\
\text { PF } 15 \%\end{array}$ & $15 \% \mathrm{CP}$ & $\begin{array}{l}15 \% \text { carbamide } \\
\text { peroxide }\end{array}$ & $\begin{array}{l}15 \% \text { carbamide peroxide, } 0.5 \% \text { potassium } \\
\text { nitrate, } 0.11 \% \text { fluoride ion }\end{array}$ & $\begin{array}{l}\text { Ultradent, Products } \\
\text { Inc., South Jordan, UT, } \\
\text { USA }\end{array}$ \\
\hline
\end{tabular}

아이오노머 $\operatorname{Ketac}^{\mathrm{TM}}$ Molar $\operatorname{Easymix(3M}$ ESPE, Seefeld, Germany)로 모든 재료의 shade는 A2로 선택하였다. 치아미 백제는 자가미백용 15\% 과산화수소(Opalescence PF 15\%, Ultradent, USA)를 사용하였다〈Table 1〉.

\section{2. 연구방법}

시편제작과 색, 미세경도, 거칠기 등의 측정방법은 선행연 구 $^{14)}$ 의 방법으로 실시하였다.

\section{1. 시편제작}

시편제작은 직경이 $8 \mathrm{~mm}$, 높이는 $5 \mathrm{~mm}$ 의 아크릴 몰드를 사용하였다. 편평한 유리판 위에 polyester film을 올리고 그 위에 몰드를 위치시킨 후 내부에 각각의 수복재를 2 3 mm 주입한 후 기포가 생기지 않도록 레진 충전용 기구로 충전하

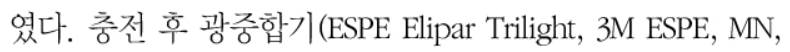
USA)로 40초 동안 중합한 후, 나머지 부위에 다시 수복재를 주입하고 윗면은 slide glass로 눌러 여분의 레진을 제거한 제거하였다. 글라스 아이오노머는 15분 후에, 복합레진과 컴 포머는 광중합기로 시편 상하면을 각 각 40초간 광중합한 후에 시편을 몰드에서 제거하였다. 모든 시편은 24 시간 동안 $37^{\circ} \mathrm{C}$ 증류수에 보관하였다. 24시간 후 각 시편을 silicone carbide paper(1200, 2400 grit)를 이용하여 주수 하에 표면연 마 한 후 초음파로 세척한 다음 24 시간 동안 증류수에 보관하 였다.

시편을 총 88 개 제작하여 증류수를 이용한 대조군과 $15 \%$ 과산화요소를 이용한 실험군으로 나누고 다시 각각 군을 4 개 의 하위그룹으로 분류하여 11 개씩 배정하였다.

\section{2. 탈회 용액, 재광화 용액 및 양치액 용액 제조} 법랑질 탈회를 위한 용액은 수산화인산칼슘(calcium phosphate-tribasic, Sigma, Usa)이 50\% 포화된 0.1M 젖산(lactic acid, Sigma, USA)과 Carbopol 0.2\%( $\# 907, \mathrm{BF}$ Goodrich, USA) 를 이용하여 $\mathrm{pH} 5.0$ 용액으로 만들어 37도 항온상태로 보관 하였다 ${ }^{15)}$. 재광화용액은 인공타액과 사람의 자극성 타액을 $1: 1$ 로 혼합하여 사용하였다. 인공타액은 $2000 \ell$ 의 증류수에 위점액소(gastric mucin, Sigma, USA) $0.22 \%$, 염화칼륨(KCl, Sigma, USA) $0.1114 \%$, 제2수화인산칼륨(KH2PO4, Sigma, USA) $0.0738 \%$, 염화나트륨(NaCl, Duksan Pure Chemical Co. Ltd., South Korea) 0.0738\%, 염화마그네슘(MgCl2, Sigma, USA) $1.033 \%$, 염화칼슘 $(\mathrm{CaCl} 2.2 \mathrm{H} 2 \mathrm{O}$, Sigma, USA) $0.0213 \%$ 로 구성하였고 $\mathrm{pH}$ 6.8로 조절하여 사용하였다. 자극성타액은 전신질환이 없는 20 대 30 명의 사람에게서 $0.5 \mathrm{~g}$ 의 파라핀 왁 스를 씹어서 얻은 후 원심 분리하여 상층액만을 이용하였다 15) 양치액은 실험용 양치액과 재광화 용액을 1:1의 비율로 제조하여 사용하였다.

\section{3. 치아 미백}

$15 \%$ 과산화요소군은 제조사의 지시에 따라 시편 표면에 균일하게 미백제를 도포하였고, 치아미백은 14 일 동안 4 시간 씩 시행하였으며 구강 내 상태를 재현하기 위해서 $\mathrm{pH}$ 순환 모형을 이용하였다. 미백 후 표면은 증류수와 부드러운 브러 시를 이용하여 제거한 후 $37^{\circ} \mathrm{C}$ incubator에 해당 용액으로 보관하였고, 증류수군의 용액은 14 일간 매일 증류수로 교환 하였다. 
Table 2. Daily process of $\mathrm{pH}-$ cycling model

\begin{tabular}{ll}
\hline \multicolumn{1}{c}{ Time } & \multicolumn{1}{c}{ Process } \\
\hline $08: 00-08: 03$ & Mouthrinsing solution(dentifrice + salivary = slurry) \\
$08: 03-12: 00$ & Remineralizing solution(artificial saliva) \\
$12: 00-12: 03$ & Mouthrinsing solution(dentifrice + salivary $=$ slurry) \\
$12: 03-14: 00$ & Remineralizing solution(artificial saliva) \\
$14: 00-18: 00$ & Demineralizing solution(0.1 M lactic acid $+0.5 \%$ carbopol) \\
$18: 00-18: 03$ Mouthrinsing solution(dentifrice + salivary $=$ slurry) \\
$18: 03-22: 03$ Tooth bleaching \\
$22: 03-08: 00$ Remineralizing solution(artificial saliva)
\end{tabular}

\section{4. $\mathrm{pH}$ 순환처리}

구강환경을 재현하기 위해 $\mathrm{pH}$ 순환 모형을 이용하였다 ${ }^{16)}$. 모든 용액은 온도를 $37^{\circ} \mathrm{C}$ 로 유지하면서 구강 내 타액만 존재 하는 시간에는 재광화용액(remineralization solution), 음식을 섭취했을 때 $\mathrm{pH}$ 가 떨어지는 시간에는 탈회 용액(demineralization solution), 양치액을 이용한 시간에는 양치용액 (Mouthrinsing solution)으로 나눠 이상의 과정을 14 일 동안 반복하였다〈Table 2$\rangle$.

\section{5. 색 측정}

수복재의 색변화를 표준화되고 측정 가능한 평가를 위하여, 색차계를 이용하여 CIELab-system의 L*a*b*값을 분석하였다. 본 연구에서는 색계측 분광분석기(Spectrophotometer, CM3500D, Minolta, Japan)를 이용하였고 미백 처리 전과 미백 후에 측정하였다. 치아 표면을 증류수로 세척한 후 건조한 다음 SCI(specular component included) mode와 표준 광원 D65 조건에서 측정부의 지름 $4 \mathrm{~mm}$ 에 가능한 시편의 중앙을 향하도록 하여 시편에 긴밀히 접촉시켜 각 5 회 측정하였고, 평균값을 그 치아의 CIE L*a*b* 값으로 선택하였다. 본 연구에 서 적용한 CIE L*a*b* 표색계는 측색으로 얻어진 값을 표시하 는 방법으로 $\mathrm{CIE}$ (국제조명연구회)에서 1976년 규정한 것이 다. 이 측정값은 각 시편의 인지가능한 색 변화량을 평가할 수 있게 해주는 것으로 밝기 즉 흰색-검은색(L), 적색-녹색(a), 황색-청색(b)의 요소를 가진 일정한 색공간이다. 색 변화를 알아보기 위하여 색 변화량 $\left(\triangle \mathrm{E}^{*}\right)$ 을 아래의 공식을 이용하여 환산하였다.

$$
\triangle \mathrm{E}^{*}=\left\{\left(\triangle \mathrm{L}^{*}\right)^{2}+\left(\triangle \mathrm{a}^{*}\right)^{2}+\left(\triangle \mathrm{b}^{*}\right)^{2}\right\}^{1 / 2}
$$

\section{6. 표면 미세경도 측정}

미백 처리 전과 미백 후에 미세 경도기(Vickers hardness tester-HV, DMH-2, Matusawa Seiki, Japan)를 이용하여 측정 하였다. 측정부위 표면에 수직이 되게 $9.087 \mathrm{~N}$ 의 하중을 10 초 간 가하고 형성된 다이아몬드형 압흔을 만든 후 압흔의 장축
길이를 측정하였다. 측정 현미경의 배율을 400 배로 하여 한 시편 당 5 회씩 측정하여 평균치를 산출하였다. 미세경도 감 소율(percentage microhardness loss, PML)은 미백 전 미세경 도 값으로 $\mathrm{VHN}(\mathrm{B})$, 미백 후 미세경도 값은 $\mathrm{VHN}(\mathrm{A})$ 로 나타내 어 PML을 구했다. 식은 다음과 같다.

$$
\operatorname{PML}(\%)=\frac{V H N(B)-V H N(A)}{V H N(B)} \times 100
$$

\section{7. 표면거칠기 측정}

제작된 시편의 미백 전과 후의 평균 표면 조도값(Ra)을 조 도 측정기(Surface Roughness Tester, Profiler Brook Contour GT, USA)을 이용하여 측정하였다. cut off 치 $0.25 \mathrm{~mm}$ 조건에 서 해당 면을 5 회 측정한 후 평균값을 구하였다. Ra 값은 측정 길이 내의 중심선으로부터 표면 윤곽까지의 모든 절대 값의 평균치로 정의되는 평균 조도값을 나타낸다.

\section{8. 통계분석}

이 모든 분석은 SPSS program(SPSS 12.0 for windows, Chicago, USA)을 이용하여 각 군의 $\triangle \mathrm{L}^{*}$ 값과 $\triangle \mathrm{E}^{*}$ 값의 변화, 미세경도 값, 그리고 거칠기 값의 차이는 ANONA와 t-test를 사용하여 검정하였다. 군간 유의한 차이가 있을 경우 Tukey multiple comparisons test $(\mathrm{p}=0.05)$ 로 검정하였다.

\section{연구성적}

\section{1. 색 측정}

14 일간 치아미백 후 모든 심미수복재의 색 계측 결과 $15 \%$ 과산화요소군이 증류수군에 비해서 $\mathrm{L}^{*}$ 값이 증가하였고 〈Table 3〉, $\triangle \mathrm{E}^{*}$ 값도 증가하였다〈Table 4〉. 증류수군의 $\mathrm{L}^{*}$ 값은 모든 군에서 미백 전과 후에 유의한 차이가 없었다 (p) 0.05). $15 \%$ 과산화요소군에서는 Z350과 P60은 미백 전과 후에 차이가 없으나, $\mathrm{DY}$ 와 $\mathrm{KM}$ 군에서는 통계적으로 유의한 
Table 3. Color changes $\left(\mathrm{L}^{*}\right)$ of the restorative materials

\begin{tabular}{|c|c|c|c|c|}
\hline Material & Bleaching & Control & $15 \% \mathrm{CP}$ & $p$ \\
\hline Z350 & $\begin{array}{l}\text { Before } \\
\text { After }\end{array}$ & $\begin{array}{l}60.84 \pm 0.5 \\
61.21 \pm 2.5\end{array}$ & $\begin{array}{l}60.97 \pm 0.5 \\
69.09 \pm 2.1\end{array}$ & $>0.05$ \\
\hline P60 & $\begin{array}{l}\text { Before } \\
\text { After }\end{array}$ & $\begin{array}{l}59.77 \pm 2.6 \\
61.67 \pm 2.2\end{array}$ & $\begin{array}{l}60.49 \pm 1.5 \\
70.85 \pm 2.8\end{array}$ & $>0.05$ \\
\hline DY & $\begin{array}{l}\text { Before } \\
\text { After }\end{array}$ & $\begin{array}{l}56.78 \pm 1.8 \\
58.05 \pm 2.6\end{array}$ & $\begin{array}{l}57.47 \pm 3.3 \\
91.62 \pm 0.8^{*}\end{array}$ & $\left\langle 0.05^{j * *}\right.$ \\
\hline $\mathrm{KM}$ & $\begin{array}{l}\text { Before } \\
\text { After }\end{array}$ & $\begin{array}{l}58.24 \pm 3.9 \\
60.33 \pm 3.0\end{array}$ & $\begin{array}{l}58.32 \pm 1.7 \\
89.67 \pm 2.6^{*}\end{array}$ & $\left\langle 0.05^{* * *}\right.$ \\
\hline
\end{tabular}

Values are reported as the Mean \pm Standard deviation

*Denoted significance between before and after bleaching by t-test

***atenot significance between control and 35\% HP group by ANOVA

Table 4. Color changes $\left(\Delta \mathrm{E}^{*}\right)$ of the restorative materials

\begin{tabular}{|c|c|c|c|}
\hline Material & Control & $15 \% \mathrm{CP}$ & $p$ \\
\hline Z350 & $1.1 \pm 0.6$ & $1.9 \pm 0.2$ & $>0.05$ \\
\hline P60 & $1.0 \pm 1.4$ & $2.2 \pm 1.8$ & $>0.05$ \\
\hline DY & $1.8 \pm 2.8$ & $4.9 \pm 1.5$ & $\left\langle 0.05^{*}\right.$ \\
\hline $\mathrm{KM}$ & $2.0 \pm 1.3$ & $4.5 \pm 2.2$ & $\left\langle 0.05^{*}\right.$ \\
\hline
\end{tabular}

Values are reported as the Mean \pm Standard deviation

*Denoted significance between control and 35\% HP group by ANOVA

차이를 보였다 $(\mathrm{p}<0.05)$. 또한 $\triangle \mathrm{E}^{*}$ 값에서도 $\mathrm{DY}$ 와 $\mathrm{KM}$ 군에서 는 통계적으로 유의한 차이를 보였다 $(\mathrm{p}<0.05)$.

\section{2. 표면미세경도 측정}

미백 전과 미백 후의 표면미세경도 값은 〈Table 5〉와 같다. 증류수군에서 미백 전 강도는 Z350은 87.81, P60은 64.94, $\mathrm{DY}$ 는 57.20 그리고 $\mathrm{KM}$ 은 54.02로 나타났다. 14일간 미백 후에는 각각에서 $86.20,62.36,54.27,51.55$ 로서 조금 감소하 였으나 통계적인 차이는 없었다(p>0.05). $15 \%$ 과산화요소군 의 미백 전 경도 값은 $\mathrm{Z350}$ 은 $88.97, \mathrm{P} 60$ 은 64.88 , DY는 57.92 그리고 $\mathrm{KM}$ 은 54.88 로 나타났다. 미백 후에는 각각에서 84.52 ,
$60.42,44.13,41.04$ 로서 전체적으로 미백 전에 비해 미백 후 경도가 감소하였다. Z350과 $\mathrm{P} 60$ 은 통계적인 차이가 없으나 (p>0.05), DY와 KM에서는 통계적으로 유의한 차이를 보였다 (p<0.05). 미세경도 감소율을 보면 증류수군에서는 1.8 $5.1 \%$ 이며, $15 \%$ 과산화요소군에서는 $5.0 \sim 25.2 \%$ 를 보였고, $\mathrm{KM}$ 에서 가장 높게 나타났다〈Table 6〉.

Table 5. Microhardness values of the restorative materials

\begin{tabular}{|c|c|c|c|c|}
\hline Material & Bleaching & Control & $15 \% \mathrm{CP}$ & $p$ \\
\hline \multirow[t]{2}{*}{ Z350 } & Before & $87.81 \pm 2.9$ & $88.97 \pm 2.3$ & \multirow{2}{*}{$>0.05$} \\
\hline & After & $86.20 \pm 1.8$ & $84.52 \pm 2.8$ & \\
\hline \multirow[t]{2}{*}{ P60 } & Before & $64.94 \pm 2.8$ & $64.88 \pm 3.2$ & \multirow{2}{*}{$>0.05$} \\
\hline & After & $62.36 \pm 1.9$ & $60.42 \pm 3.1$ & \\
\hline \multirow[t]{2}{*}{ DY } & Before & $57.20 \pm 2.1$ & $57.92 \pm 4.3$ & \multirow{2}{*}{$\left\langle 0.05^{\text {*** }}\right.$} \\
\hline & After & $54.27 \pm 1.0$ & $44.13 \pm 3.0^{*}$ & \\
\hline \multirow[t]{2}{*}{$\mathrm{KM}$} & Before & $54.02 \pm 1.8$ & $54.88 \pm 5.0$ & \multirow{2}{*}{$\left\langle 0.05^{* * *}\right.$} \\
\hline & After & $51.55 \pm 2.5$ & $41.04 \pm 2.1^{*}$ & \\
\hline
\end{tabular}

Values are reported as the Mean \pm Standard deviation

"Denoted significance between before and after bleaching by t-test

* Denoted significance between control and 35\% HP group by ANOVA 
Table 6. The percentage of microhardness loss

\begin{tabular}{|c|c|c|c|}
\hline Material & Control & $15 \% \mathrm{CP}$ & $p$ \\
\hline Z350 & $1.8 \pm 2.1$ & $5.0 \pm 0.4$ & $>0.05$ \\
\hline P60 & $3.9 \pm 0.8$ & $6.8 \pm 1.2$ & $>0.05$ \\
\hline DY & $5.1 \pm 1.4$ & $23.8 \pm 0.7$ & $\left\langle 0.05^{*}\right.$ \\
\hline $\mathrm{KM}$ & $4.5 \pm 1.7$ & $25.2 \pm 1.3$ & $\left\langle 0.05^{*}\right.$ \\
\hline
\end{tabular}

Values are reported as the Mean \pm Standard deviation

"Denoted significance between control and 35\% HP group by ANOVA

\section{3. 표면거칠기 측정}

심미수복재의 미백 전과 미백 후의 표면 거칠기를 측정한 결과는 〈Table 7〉과 같다. 증류수군에서 미백 전 거칠기 값을 보면 Z350은 $0.05, \mathrm{P} 60$ 은 $0.07, \mathrm{DY}$ 는 $0.09, \mathrm{KM}$ 은 0.11 이고, $15 \%$ 과산화요소군에서는 각각 $0.06,0.07,0.08,0.11$ 로 측정 되었다. 미백 후 증류수군은 각각 $0.06,0.08,0.11,0.13$ 으로 미백 전 값과 차이가 없었다(p>0.05). 하지만 $15 \%$ 과산화요 소군에서는 각각 $0.12,0.15,0.39,0.47$ 로 나타났다. 따라서 $15 \%$ 과산화요소군은 미백 전에 비해 미백 후에 거칠기 값이 증가하였다. 특히 $\mathrm{DY}$ 와 $\mathrm{KM}$ 은 미백 전과 후, 대조군과 비교했 을 때 통계적으로 유의한 차이를 보였다(p<0.05).

\section{총괄 및 고안}

심미수복재에 의한 치아의 수복은 과거 단순한 해부학적 및 기능적 치아 수복의 개념에 심미적 수복이라는 새로운 개념 을 더하게 되었다. 최근에는 전치부와 같이 비교적 하중이 작은 부위의 심미적 충전에 사용되던 수복재들이 무기 첨가물 (inorganic filler)의 개선과 함량의 증가 그리고 새로운 중합 방법들의 개발에 의해 큰 하중이 가해지는 구치부의 충전에도
점차 사용이 증가 되고 있다. 이와 더불어 자연치에 대한 치아 미백의 관심이 증대되면서 구강 내 존재하는 심미수복재에 미치는 영향이 있을 것으로 사료된다. 치아미백의 기전은 아 직 정확히 밝혀지지 않았으나 주성분인 과산화수소에 의한 것으로 알려져 있다. 과산화수소는 구강 내에서 분해되어 자 유 라디칼과 활성 산소(oxygen radical)를 형성하며 이렇게 생성된 활성산소는 치아에 침투되어 치아의 변색을 초래하는 착색물질과 화학반응을 하여 미백효과를 갖게 된다 ${ }^{17)}$.

치아미백 후 색변화를 보면 Yalsin과 Gürgan ${ }^{18}$ 은 $10 \%$ 과산 화요소와 $6.5 \%$ 과산화수소를 이용한 연구에서 DY가 가장 큰 색변화를 보였고, 복합레진에서는 거의 변화가 없었으며, 전체 과산화수소 농도가 높은 미백제에서 수복재의 색 변화 가 컸다. Ruyter 등 ${ }^{19}$ 은 $\triangle \mathrm{E}$ 값이 2 3정도는 색으로 지각 할 수 있는 수치이며, 3.3 정도는 인간의 눈으로 인지 가능한 변색 수준이라고 했다. 본 연구 결과에서도 복합레진에 비해 $\mathrm{DY}$ 군과 $\mathrm{KM}$ 군에서 가장 많은 색 변화를 보였다. 하지만 복합 레진의 색 변화정도는 임상적으로 의미가 크지 않는 범위이 다. RaO 등 $^{20}$ 의 연구에서는 복합레진의 색 변화는 레진의 색 상 차이, 화학적인 활성제, 개시제와 억제제, 고분자의 품질 과 종류, 필러의 양과 입자 크기, 이중결합의 관계, 레진의 두께, 혹은 관찰 기간 동안 시편의 보관 방법에 따라 영향을

Table 7. Surface roughness values $(\mathrm{Ra})$ of the restorative materials

\begin{tabular}{|c|c|c|c|c|}
\hline Material & Bleaching & Control & $15 \% \mathrm{CP}$ & $p$ \\
\hline \multirow{2}{*}{ Z350 } & Before & $0.05 \pm 0.07$ & $0.06 \pm 0.06$ & \multirow{2}{*}{$>0.05$} \\
\hline & After & $0.06 \pm 0.07$ & $0.12 \pm 0.04$ & \\
\hline \multirow{2}{*}{ P60 } & Before & $0.07 \pm 0.02$ & $0.07 \pm 0.04$ & \multirow{2}{*}{$>0.05$} \\
\hline & After & $0.08 \pm 0.03$ & $0.15 \pm 0.08$ & \\
\hline \multirow{2}{*}{ DY } & Before & $0.09 \pm 0.05$ & $0.08 \pm 0.06$ & \multirow{2}{*}{$\left\langle 0.05^{* \mid x_{1}}\right.$} \\
\hline & After & $0.11 \pm 0.08$ & $0.39 \pm 0.03^{*}$ & \\
\hline \multirow{2}{*}{$\mathrm{KM}$} & Before & $0.11 \pm 0.04$ & $0.11 \pm 0.03$ & \multirow{2}{*}{$\left\langle 0.05^{* *}\right.$} \\
\hline & After & $0.13 \pm 0.04$ & $0.47 \pm 0.04^{*}$ & \\
\hline
\end{tabular}

Values are reported as the Mean \pm Standard deviation

* Denoted significance between before and after bleaching by t-test

* Denoted significance between control and 35\% HP group by ANOVA 
받을 수 있다고 하였다. 따라서 본 연구에서는 측정에 나타날 수 있는 여러 변수를 줄이기 위해 수복재의 색상, 측정방법, $\mathrm{pH}$ 순환처리를 동일하게 시행하였다. $\mathrm{Li}$ 등 $^{21)}$ 의 in situ 연구 에서는 $15 \%$ 의 과산화요소가 함유된 자가미백제가 nano 타입 의 복합레진과 packable용 복합레진에 통계적으로 유의한 색 변화를 가졌으나 임상적으로는 수용할 수 있는 범위에 속한 다고 하였다. 이는 methacrylate를 기본으로 하는 수복재가 미백제에 대하여 색 안정성이나 느린 색변화를 보였던 기존 연구와도 일치하였다. CIE L*a* $\mathrm{b}^{*}$ 표색계에서 L* 값의 증가는 $\triangle \mathrm{E}^{*}$ 값의 증가와 밀접한 관계가 있다. 본 연구에서도 $\mathrm{L}^{*}$ 값이 가장 많이 증가한 $\mathrm{DY}$ 군과 $\mathrm{KM}$ 군은 $\triangle \mathrm{E}^{*}$ 값도 4.9 와 4.5 로 높게 나타나 임상적으로 유의한 수준의 색변화를 보였다. 컴 포머와 글라스 아이오노머 제품의 가장 큰 특성은 물을 잘 흡수하는 성질로 본 연구에서도 과산화수소의 흡수율이 복합 레진 보다 크기 때문에 색 변화가 더 큰 것으로 사료된다. RaO 등 ${ }^{20}$ 의 연구에서는 14 일간 $6 \%$ 와 $20 \%$ 과산화요소로 미백 후 글라스 아이오노머의 $\triangle \mathrm{E}^{*}$ 값이 11.4 로 유의한 색변화가 나타났다고 했다. 따라서 심미 수복재가 있는 구강상태에서 는 미리 치아 미백 전에 미백 후 색 변화가 있을 수 있으며, 필요한 경우 새로운 심미 수복재료로 교체가 필요할 수 있음 을 충분히 설명해야 할 것으로 사료된다.

Plotino 등 ${ }^{22}$ 은 수복재의 SEM 표면 분석을 통해서 미백제 로 인한 수복재 표면이 용해(dissolution)되는데 용해된 표면 에 미세한 균열이나 구멍(pore)들이 생성되고 이 구멍에 물 과 타액이 들어가면서 표면 반사로 $\mathrm{L}^{*}$ 값이 증가하였고, 치아 미백제에 의한 표면 용해는 수복재 안으로 미백제가 얼마만 큼 침투되느냐에 달려 있다고 하였다. $\mathrm{Li}$ 등 ${ }^{21)}$ 은 $\mathrm{DY}$ 의 색 변화를 일으키는 원인은 표면 용해와 구성요소의 부분적 산 화로서 미백제가 수복재 안으로 들어가는 침투 깊이에 따라 달라지며, 만약 수복재가 높은 분자량의 중합체 분자에 의하 여 단단하게 가교 결합되어 있다면, 미백제는 수복재를 용해 하는데 있어 보다 많은 시간이 필요하다고 하였다. 복합 레 진인 Z350과 $\mathrm{P} 60$ 이 컴포머에 비하여 미백젤에 덜 민감한 것은 methacrylate를 기본으로 하는 수복제는 미백제가 수복 물의 표면에 침투하는 것에 덜 영향을 주어 색 안정성이나 느린 색변화를 보였던 기존 연구 결과와 일치한다고 하겠다. Yap 등 ${ }^{23)}$ 은 컴포머가 물을 흡수하고 팽창하는 성질이 있어 필러간의 파괴로 이어지고 표면 반사가 커져 명도가 증가된 다고 하였다.

미백 후 미세경도 감소율(PML)을 보면 증류수군에서는 1.8 $\sim 5.1 \%$ 를 보여 거의 차이가 없었으나, $15 \%$ 과산화요소군에 서는 $5.0 \sim 25.2 \%$ 정도로 미세경도가 감소하였다. 이전의 $35 \%$ 과산화수소를 이용한 연구 ${ }^{14}$ 에서는 $6 \sim 34 \%$ 의 미세경도
감소가 보였으며, 이는 과산화수소 농도가 높아 자유라디컬 이 수복재 표면에 더 많은 영향을 준 것으로 사료된다. 치아 미백제가 복합레진의 미세경도에 미치는 영향에 대해서는 많은 연구에서 상반되는 결과를 보고하고 있는데 Turker와 Biskin $^{10)}$, Bailey와 Swift ${ }^{11)}$ 의 연구에서는 $10 \%$ 과산화요소 미 백제에서 통계적으로 유의한 수준의 강도 저하를 보였다고 하였다. 하지만 Compos 등 ${ }^{24}$ 은 $10 \%$ 와 $15 \%$ 과산화요소에서 레진표면의 강도 변화는 없으나, 컴포머와 hybrid ionomer에 서는 경도가 감소했다고 하였다. Poldorou 등 ${ }^{25)}$ 은 $15 \%$ 과산 화요소를 이용하여 4 종류 복합레진의 경도를 조사한 결과 미백 후 통계적으로 유의한 차이가 없다고 했다. Hao 등은 $15 \%$ 과산화요소를 이용하여 미백 트레이에 복합레진을 접착 시킨 in-vivo 실험에서 미세경도에는 유의미한 변화가 없다 고 하였다. 본 연구에서는 복합레진은 레진 내에 필러가 다 량 함유되어 있어 치아 미백 후 경도 변화가 DY군과 $\mathrm{KM}$ 군에 비해 적었으나, DY군과 $\mathrm{KM}$ 군에서는 복합레진에 비해 경도 가 다 감소하였다. $\mathrm{HaO}$ 등 $^{26}$ 의 연구에서는 수복재의 경도 감소는 분해산물인 자유라디칼이 중합체 결합의 분해를 유 발해서 가장 취약한 부분의 미반응 이중결합을 공격하여 분 해시키고 이로 인해 감소된 물질량이 표면 미세경도 감소로 나타나게 되며, 자유라디칼은 레진-필러 계면에도 영향을 주 어서 강도 저하를 유발할 수 있다고 했다.

거친 표면을 갖는 수복물은 수복 후의 표면의 거친 촉감에 의한 환자의 불편감이 생길 수 있으며, 표면 에너지를 높여 치태와 잔사의 침착을 가속화시킴으로써, 치은염 및 이차우 식증 등을 유발시킬 수 있고, 자연치 법랑질과 유사한 색조, 형태 등을 재현하기 어렵다 ${ }^{27}$. Weitman 등 $^{28)}$ 은 복합레진에 서 치태축적을 발생하는 표면 거칠기를 $0.7 \sim 1.44 \mu \mathrm{m}$ 라고 보고하였다. Bollen 등 이는 구강 내 수복물에 대한 세균 부착 의 역치에 해당하는 평균 표면 거칠기는 $0.2 \mu \mathrm{m}$ 이며, 그 이하 의 경우에는 더 이상 세균의 축적이 증가하지 않고 그 이상 에서는 거칠기가 증가할수록 치태 축적도 증가한다고 하였 다. 또한 거친 수복물의 표면은 색소 침착에 따른 착색과 변색 등으로 색조의 안정성을 저하시킴으로써 수복물을 재 수복 해야 하는 결과를 초래한다고 하였다. Mor 등ㄹㅇㅢ 연구 에서는 $10 \%$ 과산화요소로 미백한 표면에서 $S$ mutans와 $S$ sobrinus의 접착이 증가했다. Bailey 등 ${ }^{11}$ 과 Turker와 Biskin $^{10)}$ 은 10 16\% 과산화요소 미백제가 미백 후 복합레진 표면의 거칠기와 다공성을 증가시키고 SEM 측정 결과 crack 이 발견되었다고 하였다. Gurgan 등이 의 연구에서는 수복재 가 $10 \%$ 과산화요소와 $6.5 \%$ 과산화수소 치아미백에서 표면 거칠기는 증가하였고 경도는 감소하였다고 보고하였다. 본 연구에서는 Z350과 $\mathrm{P} 60$ 은 미백 후 표면 거칠기 값은 약간씩 
증가하였으나 통계적으로 유의하지 않았다. 하지만 DY와 $\mathrm{KM}$ 은 미백 후에 거칠기 값이 각 각 $0.39 \mu \mathrm{m}$ 와 $0.47 \mu \mathrm{m}$ 로서 미백 전에 비해 유의한 차이를 보였다. 이는 $\mathrm{DY}$ 와 $\mathrm{KM}$ 의 표면에 과산화수소의 자유 라디컬에 영향을 받아 수분의 흡수도 증가하여 명도 변화가 나타났고, 표면 거칠기 증가한 결과라 하겠다. Yap 등 ${ }^{23)}$ 은 수복재의 물 흡수는 부식을 일으 켜 전체 또는 일부의 필러(filler)가 탈락이 되고 갈라져서 표면거칠기가 증가했다고 하였다. Wattanapayungkul 등 ${ }^{31}$ 은 $10 \%$ 와 $15 \%$ 과산화요소를 함유한 미백제로 미백한 후 수복재의 표면 거칠기의 변화를 본 결과, 컴포머는 물 흡수 가 응력 부식과 필러의 전체 혹은 부분적인 분리를 가져와 균열을 만들어 표면 거칠기를 증가시키며, 과산화수소에 의 한 free radical이 레진-필러의 계면에 영향을 주어 필러와 기질의 분리를 야기하고 균열을 증식시켜 표면 거칠기를 극적으로 증가시키게 된다고 하였다. 또한 SEM 사진에서는 고농도의 $15 \%$ 과산화요소 미백제는 $10 \%$ 과산화요소에 비 해 표면이 더 용해되어 표면 거칠기가 유의하게 증가되었고, 광범위한 균열이 발견되었다고 하였다. 심미수복재들은 구 강내에서 색상과 표면거칠기 및 경도 등을 오랫동안 유지하 여야 하며 또한 다른 물성도 변화가 없어야 한다 ${ }^{32}$. 하지만 글라스 아이오노머와 컴포머는 복합레진과 달리 재료의 구 성에 차이가 있어 치아 미백 후 색과 표면거칠기가 영향을 받고 있고 있다. 고농도의 과산화수소를 함유한 미백제를 이용하는 전문가 미백은 미백제에서 다량의 과산화수소가 방출되므로 심미수복재에 몇 가지 문제가 발생되고 있다. 자가 미백제는 전문가 미백에 사용되는 고농도의 과산화수 소가 아닌 낮은 농도의 과산화수소가 방출된다. 하지만 전 문가 미백에 비해 오랜 기간 구강 내 머물고 있어 많은 적용 시간을 갖는다. 따라서 저농도의 치아미백제도 수복재의 색 상 변화, 특성 및 부식 등에 영향을 줄 수 있고, 치아미백으로 인해 수복재의 변화가 나타나 단순히 미백 효과만이 아닌 다른 부작용이 존재 할 수 있다고 하겠다. 향후에는 저농도 자가미백제를 이용한 심미수복재의 영향에 대한 연구가 필 요하겠다. 현 연구는 구강 내 상태를 재현하기 위하여 $\mathrm{pH}$ 순환처리 하였다. 하지만 구강 내 직접 적용되는 in-vivo가 아닌 한계점을 가지고 있다.

$35 \%$ 과산화수소를 함유한 미백제가 심미수복재에 미치는 영향을 본 선행 연구 ${ }^{14}$ 와 현 연구인 $15 \%$ 과산화요소를 함유 한 미백제에 심미수복재의 색, 경도 및 거칠기를 연구를 비교 하면 비슷한 결과를 보였고 종합해 보면 다음과 같다. 심미수 복재 중 복합레진은 치아미백제에 색, 경도 및 거칠기 변화가 적었고, 콤포머와 글라스 아이오노머에는 변화를 보이는 동 일한 결과를 얻었다. 따라서 미백제의 농도, 적용 시간, 수복
재 종류 등을 고려하여 시술이 이뤄져야 할 것이다.

\section{결론}

본 연구에서는 임상에서 시술되고 있는 $15 \%$ 과산화요소를 함유한 치아미백제를 이용하여 현재 시판되어 사용되는 심미 수복재의 색과 미세경도 및 거칠기에 미치는 영향을 연구하 였다. 연구에 사용한 심미수복재는 Nanohybrid 복합레진 (Filtek Z350, Z350)과 packable 형태의 복합레진(Filtek P60, $\mathrm{P} 60)$, 컴포머(Dyract $\left.{ }^{\circledR} \mathrm{AP}, \mathrm{DY}\right)$, 그리고 글라스 아이오노머 $\left(\mathrm{Ketac}^{\mathrm{TM}}\right.$ Molar Easymix, $\left.\mathrm{KM}\right)$ 와 15\% 과산화요소를 함유한 치아미백제를 사용하였다. 시편제작은 직경이 $8 \mathrm{~mm}$, 높이는 $5 \mathrm{~mm}$ 의 아크릴 몰드를 이용하였다. 총 88 개를 제작하여 증류 수를 이용한 대조군과 $15 \%$ 과산화요소를 이용한 실험군으로 나누고 다시 각각의 군을 4 개의 하위그룹으로 분류하여 11 개 씩 배정하였다. 치아미백은 14 일 동안 구강내 상태를 재현하 기 위해서 $\mathrm{pH}$ 순환 모형을 이용하였다. 치아미백 후 심미수 복재의 색과 경도 및 거칠기에 대해 조사하였으며 연구결과 를 요약하면 다음과 같다.

1. 14 일간 치아미백 후 모든 심미수복재의 색 계측 결과 $15 \%$ 과산화요소군이 증류수군에 $\mathrm{L}^{*}$ 값과 $\triangle \mathrm{E}^{*}$ 값이 증 가하였다. 하지만 Z350과 $\mathrm{P} 60$ 은 통계적으로 유의한 차 이가 없으나(p>0.05), DY와 KM군에서는 통계적으로 유 의한 차이를 보였다(p<0.05).

2. 증류수군에서는 표면미세경도 값이 미백전과 후에 유의 한 차이가 없었다. $15 \%$ 과산화요소군은 모든 군에서 경 도 감소를 보였으나 Z350과 $\mathrm{P} 60$ 은 통계적인 차이가 없었 고(p>0.05), DY와 KM은 통계적으로 유의한 차이를 보였 다(p<0.05). 미세경도 감소율을 보면 증류수군에서는 $1.8 \sim 5.1 \%$ 이며, $15 \%$ 과산화요소군에서는 5.0 $25.2 \%$ 를 보였다.

3. 증류수군의 표면거칠기 값은 미백 전 값과 차이가 없었 다(p>0.05). 하지만 $15 \%$ 과산화요소군에서는 미백 전에 비해 미백 후에 거칠기 값이 증가하였다. 특히 DY와 $\mathrm{KM}$ 은 미백 전과 후, 대조군과 비교했을 때 통계적으로 유의 한 차이를 보였다(p<0.05).

본 연구를 통해 $15 \%$ 의 과산화요소를 함유한 치아미백제는 컴포머와 글라스 아이오노머의 색과 경도 및 거칠기에 유의 한 영향을 주는 것을 알 수 있다. 환자들에게는 기존의 수복제 가 미백 후 차이가 있을 수 있다는 것과 교체가 필요할 수 있다는 설명이 있어야 할 것이다. 또한 심미 수복재가 구강내 
존재하고 있을 때에 미백제가 무분별하게 사용되어서는 안 될 것이다.

\section{참고문헌}

1. Woo HS, Shim YS. Effect of $15 \%$ carbamide peroxide agents with and without potassium nitrate and fluoride(PF) on the tooth color and surface microhardness of human enamel. $\mathrm{J}$ of Korea Contents Association 2012; 12(1): 353-360.

2. Sulieman MA, An overview of tooth-bleaching techniques: chemistry, safety and efficacy. Periodontol 2008; 48: 148-169.

3. Fasanaro TS. Bleaching teeth: history, chemicals, and methods used for common tooth discolorations. J Esthet Dent 1992; 4(3): 71-78.

4. Haywood VB, Heymann HO. Nightguard vital bleaching. Quintessence Int 1989; 20(3): 173-176.

5. Kim IG, Kim YS, Kim YJ, et al. Clinical aspects of dental materials. 3rd ed. Seoul, Koonja. 2009, pp 49-68.

6. Liebenberg W. Another white lie?. J Esthet Restor Dent 2006; 18(3): 155-160.

7. Monaghan P, Trowbridge T, Lautenschlager E. Composite resin color change after vital tooth bleaching. J Prosthet Dent 1992; 67(6): 778-781.

8. Cooley RL, Burger KM, Effect of carbamide peroxide on composite resin. Quintessence Int 1991; 22(10): 817-821.

9. Taher NM. The effect of bleaching agents on the surface hardness of tooth colored restorative materials. J Contemp Dent Pract 2005; 15(2): 18-26.

10. Türker SB, Biskin T. The effect of bleaching agents on the microhardness of dental aesthetic restorative materials. J Oral Rehabil 2002; 29(7): 657-661.

11. Bailey SJ, Swift EJ Jr. Effects of home bleaching products on composite resins. Quintessence Int 1992; 23(7): 489-494.

12. Mor C, Steinberg D, Dogan H, Rotstein I. Bacterial adherence to bleached surfaces of composite resin in vitro. Oral Surg Oral Med Oral Pathol Oral Radiol Endod 1998; 86(5): 582-586.

13. Yalcin F, Gürgan S. Effect of two different bleaching regimens on the gloss of tooth colored restorative materials. Dent Mater 2005; 21(5): 464-468.

14. Shim YS. The effect of tooth bleaching agent contained $35 \%$ hydrogen peroxide on the color, microhardness and surface roughness of tooth-colored restorative materials. J Korean Soc Dent Hyg 2012; 12(3): 533-541.

15. Kim MY, Kwon HK, Kim BI. Remineralization effect of mouthrinse containing nano-hydroxyapatite by $\mathrm{pH}$-cycling model. J Korean Acad Dent Health 2007; 31(2): 156-166.

16. White DJ. The application of in vitro models to research on demineralization and remineralization of the teeth. Adv Dent Res 1995; 9(3): 175-193.

17. Yu H, Li Q, Lin Y, Buchalla W, Wang Y. Influence of carbamide peroxide on the flexural strength of tooth-colored restorative materials: an in vitro study at different environmental temperatures. Oper Dent 2010; 35(3): 300-307.

18. Yalcin F, Gurgan S. Bleaching-induced colour change in plastic filling materials. J Biomater Appl 2005; 19(3): 187-195.

19. Ruyter IE, Nilner K, Moller B. Color stability of dental composite resin materials for crown and bridge veneers. Dent Mater 1987; 3(5): $246-251$.

20. Rao YM, Srilakshmi V, Vinayagam KK, Narayanan LL, An evaluation of the color stability of tooth-colored restorative materials after bleaching using CIELAB color technique. Indian $J$ dent Res 2009; 20(1): 60-64.

21. Li Q, Yu H, Wang Y. Colour and surface analysis of carbamide peroxide bleaching effects on the dental restorative materials in situ. J Dent 2009; 37(5): 348-356.

22. Plotino G, Buono L, Grande NM, Pameijer CH, Somma F. Nonvital tooth bleaching: a review of the literature and clinical procedures. J Endod 2008; 34(4): 394-407.

23. Yap AU, Wang HB, Siow KS, Gan LM. Polymerization shrinkage of visible-light-cured composites. Oper Dent 2000; 25(2): 98-103.

24. Campos I, Briso AL, Pimenta LA, Ambrosano G. Effects of bleaching with carbamide peroxide gels on microhardness of restoration materials. J Esthet Restor Dent 2003; 15(3): 175-182.

25. Polydorou O, Mönting JS, Hellwig E, Auschill TM, Effect of in-office tooth bleaching on the microhardness of six dental esthetic restorative materials. Dent Mater 2007; 23(2): 153-158.

26. Hao Yu, Qing Li, Manal Hussain, Yining Wang. Effects of bleaching gels on the surface microhardness of tooth-colored restorative materials in situ. J Dent 2008; 36(4): 261-267.

27. Quirynen M, Bollen CM. The influence of surface roughness and surface-free energy on supra- and subgingival plaque formation in man. J Clin Periodontol 1995; 22(1): 1-14.

28. Weitman RT, Eames WB. Plaque accumulation on composite surfaces after various finising procedures. J Am Dent Assoc 1975; 91(1): 101-106

29. Bollen CM, Lambrechts P, Quirynen M. Comparison of surface roughness of oral hard materials to the threshold surface roughness for bacterial plaque retention: a review of the literature. Dent Mater 1997; 13(4): 258-269.

30. Gurgan S, Kiremitci A, Yalcin F, Alpaslan T, Yazici E. Effect of carbamide peroxide treatments on the metal-ion release and microstructure of different dental amalgams. Oper Dent 2007; 32(5): 476-481.

31. Wattanapayungkul P, Yap AU, Chooi KW, et al. The effect of 
home bleaching agents on the surface roughness of tooth-colored restoratives with time. Oper Dent 2004; 29(4): 398-403.

32. Moon JH, Kang YM, Oh YT, et al. Effects of hydrogen peroxide concentration and application period on the bleaching and physical properties of esthetic restorative materials. J Kor Res Soc Dent Mater 2009; 36(3): 205-220. 